says that the government wants the proportion of companies engaged in high-technology projects to grow from 12 to 20 per cent by the end of 2003.

As part of this trend, the government will provide financial support for $\mathbf{5 0 0}$ young postdocs to be recruited by Spanish companies, as well as 1,000 scientists in technology centres and small- and medium-sized companies.

There will be tax incentives for companies involved in $\mathrm{R} \& \mathrm{D}$, including a 30 per cent increase in general tax deductions and a further 10 per cent deduction for expenses related to research personnel.

Piqué points out that Spain's position on technological innovation is "not good" compared with other developed countries, and that a "great effort" will be needed, mainly from the private sector, to reach a similar level to its competitors.

He says that Spain must move beyond a 'subsidy culture', and that even though the country is ranked eleventh in the world in terms of its research output, its technological exports are "very small" compared with its imports.

At a recent meeting in Valencia with 2,000 industrial managers, Spain's prime minister, José Maria Aznar, said his government wanted investment by the private sector in $\mathrm{R} \& \mathrm{D}$ to grow by more than 10 per cent a year, to reach 65 per cent of the country's total $R \& D$ budget by the end of 2003.

Many scientists have welcomed the new posts and the budget increase. But they warn that the plan will not solve the bias towards local candidates in selection procedures.

Xavier Bosch

\title{
Opposition pledges to raise New Zealand science budget
}

\section{Sydney}

New Zealand's opposition Labour Party has promised to increase the funding for basic research by NZ $\$ 77$ million (US $\$ 40$ million) over the next three years, financed primarily from increased taxes on high-income earners, if it wins the general election next week (27 November).

The party is also promising increased taxes to raise an extra NZ\$750 million over three years, most of which would be used to ease student debt, stop fee increases and encourage students to take up science and technology.

The ruling National Party, which recently attempted to take the initiative with measures - but no new money - intended to boost the nation's research and development (see Nature 401, 106; 1999), appears to have lost some momentum on the issue.

Many scientists were disappointed that the prime minister, Jenny Shipley, gave only passing mention to research in her campaign launch, strongly defending the National Party's belief in market forces. Indications that the party would reverse its opposition to tax breaks to improve the poor research performance by industry were scotched last week by the treasurer, Bill English.

But the government-owned Association of Crown Research Institutes, through their association, are strongly supportive of the earlier package, and have declared that "it puts research centre stage in New Zealand's development".
Both Labour and the National Party have pronounced that the 'knowledge economy' is the country's route to economic salvation. But science is a less popular cause than universities, where staff and students are protesting against government policies.

These policies, which have led to rising fees and student debt, are widely cited as being behind the exodus of graduates and experienced researchers alike.

This week, New Zealand-born scientists working in the United States claimed the government's package of new scholarships would be better spent on improving research conditions in New Zealand.

Amanda Peet, a physicist at the University of California, Santa Barbara, says that higher education in New Zealand is "starved of support"

Labour's science spokesman, Mark Peck, is promising to establish New Zealand's first external body to advise the prime minister on science and technology - a significant weakening of the ministries' grip on policy.

Many are critical of the government. Mark Grimes, a member of the council of the New Zealand Association of Scientists, accuses the government of "a plot to cover up their abysmal record in funding science and education by quoting cumulative increases".

But others are sceptical of Labour's capacity to improve the situation, given that it started the problem with its cuts. The association's president, Janet Grieve, says it is not endorsing any party.

Peter Pockley

\section{Body takes centre stage in UK's Millennium Dome}

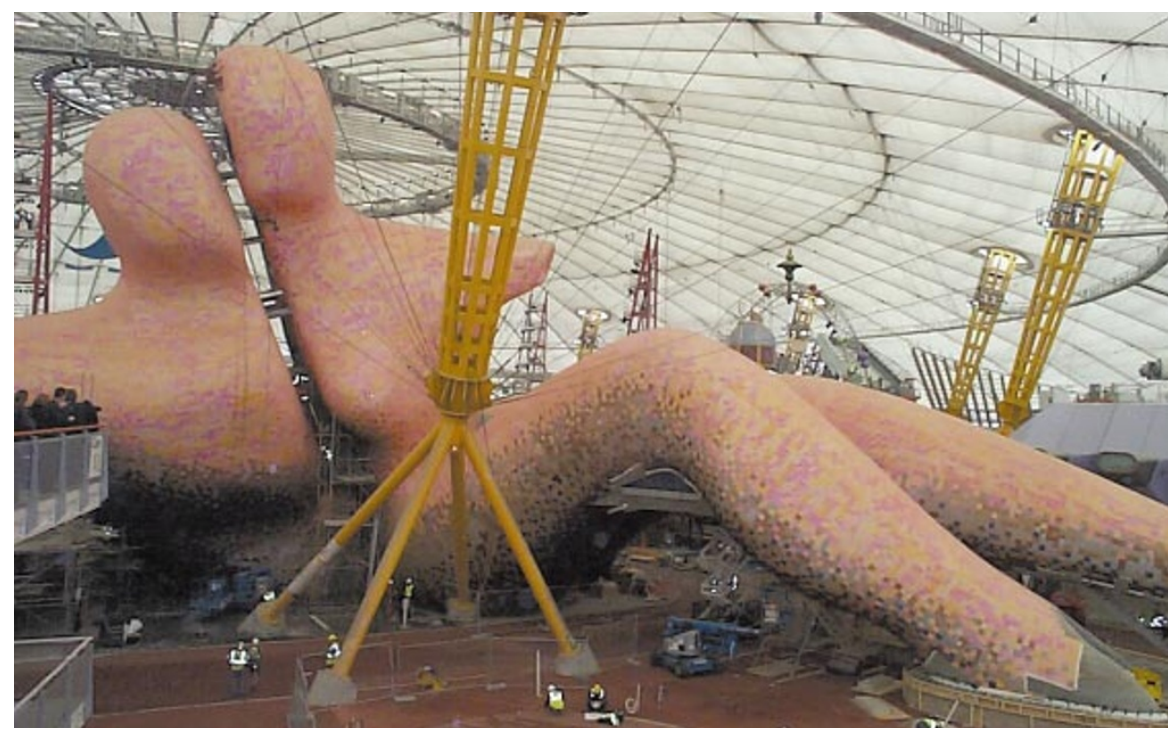

London

Some of the main attractions inside the Millennium Dome - the centrepiece of the British government's year 2000 celebrations - were unveiled last week. The Body Zone (pictured) is designed to give visitors an insight into their bodies and the discoveries, technologies and new ideas that will affect health and well-being in the future.

Visitors will walk through the giant figure and move on to exhibits on the future of drug design, robots at work in the operating theatre of the future, and an iris scanning display. The Human Genome Project will be featured in a wall of telephone directories representing the quantity of information in human DNA.

Located at Greenwich in London, the dome is expected to receive up to 12 million visitors next year.

Natasha Loder 